\title{
Education and social justice in Japan
}

\author{
Kaori H. Okano. Routledge, Abingdon/New York, 2021, 234 \\ pp. Routledge Critical Studies in Asian Education series. ISBN \\ 978-0-415-83252-6 (hbk), ISBN 978-1-315-81409-4 (eBook)
}

\section{Steve R. Entrich ${ }^{1}$}

Accepted: 21 October 2021 / Published online: 29 October 2021

(c) The Author(s) 2021

Education in Japan has been subject to major reforms over the past three decades. Many scholars have examined these reforms and their implementation and outcomes from different angles, but a comprehensive work such as this one on recent developments in Japanese education is rare. The book is a sequel to the author's collaborative work Education in contemporary Japan: Diversity and inequality (Okano and Tsuchiya 1999), ${ }^{1}$ claiming to offer an up-to-date critical examination of recent developments in schooling in Japan from the 1990s onwards. The clear focus on social justice indicated in the title suggests a limitation to issues related to student diversity and sociodemographic inequality in access to formal schooling of disadvantaged, minoritised students. However, this book delivers much more.

Overall, Okano discusses social justice in its relationship to the four main roles of modern schooling: transmission of knowledge; socialisation/enculturation; differentiation; and legitimisation. Significantly, this book approaches two different dimensions of social justice: (1) justice in terms of distribution, i.e. who gets how much schooling and under which conditions; and (2) justice in terms of curricular content, i.e. who decides what is taught to whom and how this meets the actual needs of the (diverse) student population. While the former relates to the much-debated issue of (in)equality of educational opportunities and thus mainly occupies the role of differentiation or selection of modern schooling (discussed in terms of access to education by income level, gender, migratory background and region), the latter refers to the less emphasised differences in policy decision-making and their consequences for students from diverse backgrounds.

Following a general introduction (Chapter 1), the book provides a historical review of developments in Japanese education from pre-modern times to the

\footnotetext{
1 Okano, K.H., \& Tsuchiya, M. (1999). Education in contemporary Japan: Inequality and diversity. Cambridge, UK: Cambridge University Press.
}

Steve R. Entrich

entrich@uni-potsdam.de

1 Department of Education, University of Potsdam, Potsdam, Germany 
present (Chapter 2). Discussing the concrete contents and magnitude of reforms from the 1990s onwards, Chapter 3 captures the current state of education in Japan in a very comprehensive way. This overview may not provide much new information for scholars in the field, but it is a great introduction for all newcomers eager to learn more about education in Japan. Most significant, and indeed an innovative feature of the book, is the rather controversial stance of the author arguing that despite all the measures implemented over the past years, the basic structure, mechanisms and content of schooling have not drastically changed. This position stands in stark contrast to many prominent works stressing the significance of the yutori or "relaxed education" reforms ${ }^{2}$ as some kind of turning point in Japanese education policies believed to bring about fundamental change to schooling practice. While the book illustrates very well how diversity in educational provision has vastly increased, it also exposes the reform measures for what they are: a pragmatic response to the concerns and political agendas of various political camps, "neoliberals, [...] neoconservatives, [...] humanist progressive educationalists, [...] and social justice and human rights advocates" (pp. 65f.). The author convincingly demonstrates that while recent attempts to reform education may have extended school choice and school autonomy, created alternative ways and opportunities to access higher levels of education, and reduced the achievement gap predetermined by socioeconomic status, they are at the same time failing to significantly reduce inequality in educational opportunities.

A prominent example of the increased diversity in education with clear implications for social inequality is the observable - albeit unexpected - (continuous) rise of non-formal education. Past literature particularly focused on private supplementary or "shadow" education (especially lessons offered at juku or yobikô) 3 and its impact on educational trajectories in Japan. Although the majority of Japanese students from all backgrounds attend these out-of-school lessons over the course of their school life to improve their academic achievement and subsequent chances of admission to prestigious universities, there is great social selectivity in the use of these lessons. Contrary to predictions from the 1990s, according to which shadow education would become superfluous as a result of demographic change in combination with alternative ways of entering higher levels of education as part of the yutori reforms (see Okada 2012), ${ }^{4}$ the Japanese shadow education system has in fact remained remarkably successful (see esp. Entrich 2018). ${ }^{5}$ Regrettably, this book does not go into detail about how this high-scale education industry has managed to adapt to formal educational and societal changes and resulting new needs and demands of families while

\footnotetext{
2 The aim of the yutori reforms was, essentially, to decrease the prevalent intense competition between students, lessen the pressure on students, and at the same time give them room to develop their creativity and individuality.

${ }^{3}$ While the term $j u k u$ covers a wide range of different types of cram schools, prep schools and learning centres, yobikô are special university entrance preparation schools. These private supplementary schools thus can largely differ in terms of student clientele, curriculum and fees.

${ }^{4}$ Okada, A. (2012). Education policy and equal opportunity in Japan. New York/Oxford: Berghahn Books.

5 Entrich, S.R. (2018). Shadow education and social inequalities in Japan: Evolving patterns and conceptual implications. Heidelberg: Springer.
} 
taking over functions of formal schooling and coming up with new opportunities for students from diverse backgrounds.

Instead, the book focuses in particular on the quite positive innovations in the formal and non-formal schooling of culturally and linguistically diverse (CLD) student groups, including the minoritised Ainu, Okinawan and Buraku populations with Japanese citizenship as well as the student populations with migratory backgrounds, such as Zainichi Koreans, ethnic Chinese, and newcomer migrants. Even though the number of CLD students has risen in recent years, making Japan "more culturally and linguistically diverse in the last two decades" (p. 94), Japan remains a country with one of the lowest proportions of foreign residents among highly industrialised societies. Hence, for a long time sociologists may have accepted the myth of Japan as a homogenous society, resulting in a dearth of research into educational trajectories and opportunities of CLD residents. This book presents a detailed overview of education for CLD groups and shows impressively the improvement in access to formal and non-formal education (e.g. free schools, special learning centres or gaikokujin gakkô [fulltime schools for foreigners]) for these students, which did not result so much from national politics, but rather from local initiatives.

In addition to classic sociological constructs for sociodemographic background such as migratory background (CLD: Chapter 4), socioeconomic status (especially outcomes of unequal distribution of economic resources focusing on child poverty), gender, and region (Chapter 5), the book also introduces the issue of shokuiku or "education about eating" (Chapter 6) and how this possibly enhances students' academic learning. However, readers eager to learn more about recent developments in special (or inclusive) as well as transnational education will be rather disappointed. The book studies inclusiveness of education focusing on migrant children with language disabilities in Japanese, and school absenteeism (futôkô), but does not bother to provide more than a brief summary of recent legal changes in the field of special/inclusive education, even though this is clearly related to the issue of social justice and moreover one of the most significant developments in education we have witnessed in the past few years. The international demand connected to the catchphrase "Education for All" (UN 2006) ${ }^{6}$ put much pressure on Japan to reform its special education system towards achieving more inclusive education (Mithout 2016). ${ }^{7}$ But besides noting that "the integration process has been slow" (p. 44), not much is included in the book. Similarly, the outcomes of the recent active promotion of internationalisation of education in conjunction with higher rates of Japanese studying abroad remain but a side note at best.

Despite these shortcomings, this book is a must-read for all scholars involved with or interested in education in Japan, as it gives a much-needed comprehensive

\footnotetext{
${ }^{6}$ UN (United Nations) (2006). Convention on the Rights of Persons with Disabilities. New York: United Nations. Retrieved 15 October 2021 from https://www.un.org/development/desa/disabilities/conventionon-the-rights-of-persons-with-disabilities.html.

7 Mithout, A.L. (2016). Children with disabilities in the Japanese school system: A path toward social integration? Contemporary Japan, 28(2), 165-184. https://doi.org/10.1515/cj-2016-0009.
} 
update on recent developments in the formal and non-formal parts of the education sector. I specifically recommend Okano's work to students engaged in Japanese studies, comparative education and sociology, as well as politics.

Funding Open Access funding enabled and organized by Projekt DEAL.

Open Access This article is licensed under a Creative Commons Attribution 4.0 International License, which permits use, sharing, adaptation, distribution and reproduction in any medium or format, as long as you give appropriate credit to the original author(s) and the source, provide a link to the Creative Commons licence, and indicate if changes were made. The images or other third party material in this article are included in the article's Creative Commons licence, unless indicated otherwise in a credit line to the material. If material is not included in the article's Creative Commons licence and your intended use is not permitted by statutory regulation or exceeds the permitted use, you will need to obtain permission directly from the copyright holder. To view a copy of this licence, visit http://creativecommons.org/licen ses/by/4.0/.

Publisher's Note Springer Nature remains neutral with regard to jurisdictional claims in published maps and institutional affiliations. 